\title{
Exploring the edge of a natural disaster
}

\author{
Michael W. Jenkins ${ }^{1 *}$, Dan J. Krofcheck ${ }^{1}$, Rachel Teasdale ${ }^{2,3}$, James Houpis ${ }^{4}$, \\ James Pushnik ${ }^{3,5}$ \\ ${ }^{1}$ Department of Biology, University of New Mexico, Albuquerque, USA; ${ }^{2}$ Corresponding Author: jenkins1@unm.edu \\ ${ }^{2}$ Center for Ecosyetem Research (CER), California State University, Chico, USA \\ ${ }^{3}$ Department of Geological and Environmental Science, California State University, Chico, USA \\ ${ }^{4}$ Department of Earth \& Environmental Sciences and Office of Academic Affairs, California State University, East Bay Office of the \\ Academic Affairs, East Bay, USA \\ ${ }^{5}$ Department of Biological Sciences, California State University, Chico, USA
}

Received 4 September 2012; revised 16 October 2012; accepted 24 October 2012

\section{ABSTRACT}

Natural geological, chronic and acute release of volcanic gases can have a dramatic impact on vegetative ecosystems and potential impact on regional agriculture and human health. This research incorporates a series of observations using leaf level gas exchange, chlorophyll fluorescence and remotely sensed reflectance measurements of vegetation experiencing chronic exposure to volcanic gas emissions; to develop techniques for monitoring the relative health of vegetation along the edge of an acute vegetative kill zone of a natural disaster and potential preeruption vegetation physiology. Experiments were conducted along an elevation gradient that corresponds to the $\mathrm{SO}_{2}$ gradient on vegetation along the south flank of Volcán Turrialba, Costa Rica. This study site is a natural environment with high volcanic degassing activity with significant $\mathrm{SO}_{2}$ emissions (n/d - $0.281 \mathrm{ppm}$ ). Corresponding to an $\mathrm{SO}_{2}$ gradient, a substantial increase in $\mathrm{CO}_{2}$ concentration of (430-517 ppm) was identified. We further show the physiological interactions of $\mathrm{SO}_{2}$ and $\mathrm{CO}_{2}$ have on vegetation along the kill zone of this natural disaster can be assessed by examining the $\mathrm{SO}_{2} / \mathrm{CO}_{2}$ ratios. The physiological indices tested and relationships among measurements emphasized in this research will add to the assessment of the impact atmospheric volcanic gas emissions have on the physiology of surrounding vegetation as well as advance the capability of remotely sensed environmental stress in natural settings.

Keywords: Carbon Dioxide; Chlorophyll Fluorescence; Leaf Level Gas Exchange; Natural Disaster; Remote Sensing; Sulphur Dioxide;

Volcanic Gas Emissions

\section{INTRODUCTION}

On January 4th, 2010 Volcán Turrialba entered a new phase of activity, marked by an increased number of volcanic low-frequency signal B type earthquakes and large and high gas plumes [1]. On January 5th, two minor eruptive events occurred at 2:29 pm and 2:45 pm, which emitted ash over local farming areas of La Central and La Silvia, Capellades town, finer ash at Tierra Blanca, Llano Grande and Tres Rios, and volcanic dust in eastern San Jose [1]. Two new small craters opened, which later joined and formed a fracture-like structure where gases were expelled at temperatures greater than $350^{\circ} \mathrm{C}$ [1]. Residents from nearby farms around the volcano were evacuated. On January 8th the seismic activity and ash emission decreased, but after almost 144 years of inactivity, Volcán Turrialba had renewed its eruptive activity.

It is well known that tropical forests across the globe are disappearing [2-8]. It is widely recognized that tropical forest species are being adversely affected by exploittation, land-use changes, climate change and natural geological disturbances $[7,9,10]$. Along with the importance of tropical plants for their well recognized ecological goods and services of habitat creation and global carbon balance, these ecosystems have significant implications on water and soil quality in these regions. This study is an initial examination of a natural gradient of impact established by the recent volcanic gas releases on native vegetation, but has added implications for the agricultural zone and food supply within the same vicinity and potential impact on human health.

Sulphur dioxide $\left(\mathrm{SO}_{2}\right)$ and carbon dioxide $\left(\mathrm{CO}_{2}\right)$ are among the atmospheric contaminants and phytotoxic by-products emitted during recent volcanic activity at Turrialba. This investigation attempts to characterize the pre-symptomatic effects of these naturally emitted air pollutants on the physiological performance of native plants and their potential influence on the composition and stability of the ecosystems in which the plants live. 
Leaf level gas exchange, chlorophyll fluorescence and spectral reflectance are important tools for evaluating stress and physiological impacts of air pollutants on plants $[11,12]$. The scope of this initial work was to study the effects of the recent volcanic emissions on photosynthetic activity, chlorophyll fluorescence and reflectance of plants under stress from chronic exposure to concentrations of elevated $\mathrm{SO}_{2}$ and $\mathrm{CO}_{2}$ under otherwise natural conditions.

Stress is characterized as any disturbing influence that results in physiological consequences [13]. However, by the time plants display visible symptoms of stress, they can already be adversely affected [14]. Photosynthetic reduction, increase in chlorophyll fluorescence and shifts in spectral reflectance in the absence of, or prior to, visible symptom expression could indicate suppression of growth or reduced vigor in an otherwise apparently healthy plant [15].

$\mathrm{SO}_{2}$ is a well known stress inducing agent which can cause toxicity, reduced growth, cell death, plant organ death and whole plant death; and on a larger scale can influence biological systems, environments and whole eco-regions [16]. Environmental conditions, concentrations of $\mathrm{SO}_{2}$, duration of exposure, sulphur status of soil and genetic attributes of plants determine the degree of stress and physiological impact due to the phytotoxicity of $\mathrm{SO}_{2}$ [17].

To investigate the interactive physiological effects of elevated $\mathrm{SO}_{2}$ and $\mathrm{CO}_{2}$ under naturally occurring conditions, experiments were conducted along an elevation gradient between 1939 and 3280 meters along the south flank of Volcán Turrialba, Costa Rica. Measurements were conducted along an access road, which starts in Pastora de Santa Cruz, and leads to the entrance to Parque Nacional Volcán Turrialba, and the peak of the edifice of the volcano. Volcán Turrialba is a composite stratovolcano located 25 kilometers north east of Cartago on the eastern end of the Central Volcanic Range (Cordillera Volcanica Central) and approximately 40 kilometers east of San Jose, Costa Rica (Lat. 100020 North, Long. 830 450 West) [18]. The peak of Volcán Turrialba is 3328 meters above sea level and is completely covered by vegetation except in the caldera [19]. Volcán Turrialba is the easternmost, and one of Costa Rica's largest active volcanoes.

This initial research had three main objectives: 1) to establish relationships between leaf-level gas exchange and elevated atmospheric concentrations of $\mathrm{SO}_{2}$ and $\mathrm{CO}_{2}$ related to increased volcanic emissions, 2) to identify physiological correlations between leaf-level gas exchange and chlorophyll fluorescence measurements of plants under long term stress induced by volcanically emitted $\mathrm{SO}_{2}$, and 3) to provide evidence that remotely sensed reflectance-derived fluorescence ratio indices can be used to monitor plant stress and photosynthetic functioning.

\section{STUDY PLANT}

Gunnera insignis, common name poor man's umbrella or sombrilla de pobre, was chosen as the experimental plant for this experiment (Figure 1). G. insignis is located at the peak of Volcán Turrialba and continuously at all elevations, to approximately 500 meters. G. insignis is a giant herb ranging throughout Panama, Costa Rica and Nicaragua at elevations from 500 meters to 3400 meters [20]. G. insignis inhabits moist, nutrient poor, acidic soils and is capable of establishing a symbiotic relation with a nitrogen fixing cyanbacterium (Nostoc sps.). The plant has a solitary, thick, semi-erect stem, which holds a terminal set of rounded extremely large (can reach greater than 2 square meters) lobed leaves [20], providing a large surface for gas exchange with prevailing atmospheric conditions. Plants found at the lowest elevations at which G. insignis was identified on the south flank of Turrialba (1939 meters and 2454 meters), were designated as control plants, due to minimal levels of detectable atmospheric $\mathrm{SO}_{2}$ concentration and used to run $A-C_{i}$, net $\mathrm{CO}_{2}$ assimilation rate, $A$, versus calculated substomatal $\mathrm{CO}_{2}$ concentration, $C_{i}$ response curves and light response curves.

Under natural conditions, multiple environmental stressors co-occur and can result in a wide range of physiological effects. Analysis of the $A / C_{i}$ curve and the light response curve showed sample plants in this study were neither light or $\mathrm{CO}_{2}$ stressed. The leaf temperature/air temperature ratio shows that physiological shifts toward increasing heat production, was limited, indicating minimal stress of control plants (Table 1).

\section{GAS EXCHANGE}

Simultaneous measurements of leaf level gas-exchange including $\mathrm{CO}_{2}$ assimilation rate $(A)$, stomatal conductance $\left(g_{s}\right)$, intercellular $\mathrm{CO}_{2}\left(C_{i}\right)$ and chlorophyll fluorescence parameters of steady state fluorescence $\left(F_{s}\right)$, quantum yield of PSII calculated from $\left(F_{m}^{\prime}-F_{s} / F_{m}^{\prime}\right)$, and maximum quantum yield of PSII calculated from $\left(F_{v}^{\prime} / F_{m}^{\prime}\right)$ as well as $\mathrm{CO}_{2}$ response and light response curves were taken using infrared gas analyzers and a Leaf Chamber Fluorometer (LCF) [21].

Leaf level gas exchange on $G$. insignis and atmospheric $\mathrm{SO}_{2}$ and $\mathrm{CO}_{2}$ concentrations were measured at elevations ranging between 1939 meters and 3280 meters (Table 1 and Figure 1). A steady rise in atmospheric $\mathrm{SO}_{2}$ and $\mathrm{CO}_{2}$ concentrations with a corresponding rise in elevation was detected during a 24-hour sampling period (Table 1). A few anomalies were observed; at $2773 \mathrm{~m}$, $\mathrm{SO}_{2}$ measurements were lower than the previous lower 


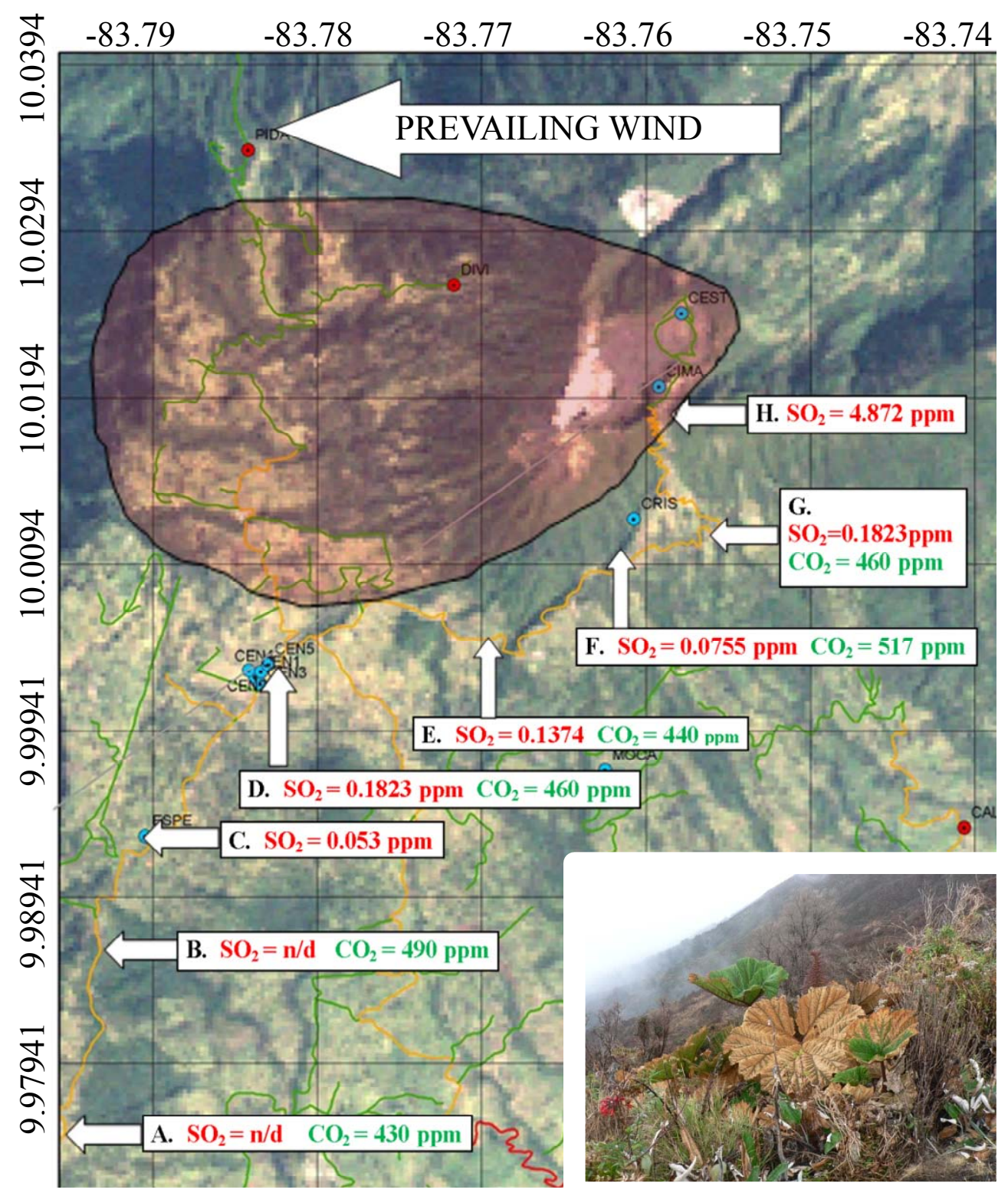

Figure 1. Map of Volcán Turrialba, access road (orange) with white arrows identifying sampling sites with elevations $\mathrm{A}=1939 \mathrm{~m}, \mathrm{~B}=2454 \mathrm{~m}, \mathrm{C}=2594 \mathrm{~m}, \mathrm{D}=2673 \mathrm{~m}, \mathrm{E}=2789 \mathrm{~m}, \mathrm{~F}=2950 \mathrm{~m}$, and $\mathrm{G}=$ 3280 meters used for $\mathrm{SO}_{2}, \mathrm{CO}_{2}$ and physiological measurements. The highlighted area is the kill zone. Image in bottom right is the study plant $G$. insignis.

elevation, and at 2789 meters there was much lower $\mathrm{SO}_{2}$ measured. These anomalies are attributed to microclimatic variations in the data collection sites. G. insignis measured at 2789 meters elevation displayed the maximum $A$ of $16.7 \mu \mathrm{mol} \mathrm{CO} \mathrm{CO}^{-2} \cdot \mathrm{s}^{-1}$ and the maximum $g_{\mathrm{s}}$ of $0.329 \mathrm{~mol} \mathrm{CO} \mathrm{m}^{-2} \cdot \mathrm{s}^{-1}$, the highest rates observed during the study.

The first objective of this research was to establish relationships between leaf-level gas exchange and elevated atmospheric concentrations of $\mathrm{SO}_{2}$ and $\mathrm{CO}_{2}$ due to geologic emissions. Due to a limitation on the time available to conduct this research it is difficult to make statistically valid comparisons. However, results may be seen as a way to gain a better understanding of the interactive impacts of naturally elevated $\mathrm{SO}_{2}$ and $\mathrm{CO}_{2}$ on the species studied under these ecologically shifting conditions bordering the edge of a natural disaster.

During this study period, volcanic gas concentrations along an elevation gradient ranged from $0.2805 \mathrm{ppm}$ to non-detectable for $\mathrm{SO}_{2}$ and from 517 to $430 \mathrm{ppm}$ for $\mathrm{CO}_{2}$. $\mathrm{SO}_{2}$ concentrations of $4.872 \mathrm{ppm}$ were identified at the edifice of Volcán Turrialba at an elevation of 3280 meters (Table 1). However, the measurements recorded at these sites are not included in the experiments described below 
Table 1. Gas exchange parameters measured on Gunnera insignis at different elevations with corresponding $\mathrm{SO}_{2}$ and $\mathrm{CO}_{2}$ concentrations.

\begin{tabular}{|c|c|c|c|c|c|c|}
\hline Elevation & $\mathrm{SO}_{2}$ & $\mathrm{CO}_{2}$ & Photo $(A)$ & $C_{\mathrm{i}}$ & Conductance $\left(g_{\mathrm{s}}\right)$ & LeafTemp/AirTemp \\
\hline (meters) & (ppm) & (ppm) & $\left(\mu \mathrm{mol} \mathrm{CO} \mathrm{Cm}^{-2} \cdot \mathrm{s}^{-1}\right)$ & $\left(\mu \mathrm{mol} \mathrm{CO}{ }_{2} \mathrm{~mol} \cdot \mathrm{air}^{-1}\right)$ & $\left(\mathrm{mol} \mathrm{CO} \mathrm{C}_{2} \mathrm{~m}^{-2} \cdot \mathrm{s}^{-1}\right)$ & $\left({ }^{\circ} \mathrm{C}\right)$ \\
\hline 1939 & $\mathrm{n} / \mathrm{d}$ & 430 & 14.9 & 278 & 0.275 & 1.03 \\
\hline 2454 & $\mathrm{n} / \mathrm{d}$ & 490 & 12.3 & 312 & 0.286 & 0.75 \\
\hline 2594 & 0.053 & - & 10.75 & 306 & 0.236 & 0.74 \\
\hline 2673 & 0.182 & 460 & 13.55 & 279.5 & 0.211 & 0.84 \\
\hline 2773 & 0.137 & 440 & 12.65 & 303 & 0.258 & 0.68 \\
\hline 2789 & 0.076 & 517 & 16.7 & 294 & 0.329 & 0.97 \\
\hline 2950 & 0.281 & 430 & 15.17 & 247.7 & 0.184 & 0.99 \\
\hline
\end{tabular}

due to extreme foliar damage and all related physiological processes. A measurements reported in this study demonstrate a weak correlation with $\mathrm{SO}_{2}$ concentrations $\left(\mathrm{r}^{2}\right.$ $=0.0575)$. Previous studies reveal that photosynthetic response to $\mathrm{SO}_{2}$ exposure depends on pollutant dose and genotype, and can either inhibit, stimulate or have no effect on photosynthesis [16]. Overall, minimal variation of carbon assimilation rates are observed among plants tested along this $\mathrm{SO}_{2}$ gradient (Table 1). Moreover, carbon assimilation rates were not correlated with other measurements in this study due to over saturating levels of $\mathrm{CO}_{2}$ as identified by the $\mathrm{A} / \mathrm{Ci}$ curve (not shown).

$g_{s}$ and $\mathrm{SO}_{2}$ concentrations are moderately correlated $\left(\mathrm{r}^{2}=0.552\right)$. Reports on effects of $\mathrm{SO}_{2}$ on $g_{s}$ are highly variable, and depend strongly on environmental and exposure conditions and $\mathrm{SO}_{2}$ concentrations [22]. Stomatal conductance has been reported as increasing at low $\mathrm{SO}_{2}$ concentrations in some species, while partial stomatal closure is induced due to high concentrations of $\mathrm{SO}_{2}[16]$. In this study A measurements are weakly correlated with $g_{s}\left(r^{2}=0.073\right)$. Differences in $\mathrm{SO}_{2}$ uptake due to different $g_{s}$ may partially explain the differences in $\mathrm{SO}_{2}$ sensitivity [23], albeit not universally.

Intercellular carbon dioxide $\left(C_{i}\right)$ and $\mathrm{SO}_{2}$ concentrations are also moderately correlated $\left(\mathrm{r}^{2}=0.514\right) . A / C_{i}$ curves developed from control plants, demonstrated as $C_{i}$ increases so does $A$. However, the correlation between $A$ and $C_{i}$ along the study site transect is moderate $\left(\mathrm{r}^{2}=\right.$ $0.331)$. In order to identify and quantify the effects of $\mathrm{SO}_{2}$ on $C_{i}$, measurements of mesophyll conductance $\left(g_{m}\right)$ should be included, but unfortunately these measurements were not made. However, the potential impacts of $\mathrm{SO}_{2}$ effects on mesophyll resistance should not be discarded. $\mathrm{SO}_{2}$ effects on photosynthesis are more likely the result of increases in mesophyll resistance (e.g. internal cellular damage), as opposed to decreases in stomatal conductance. This conclusion is consistent with results from Barton et al. (1980) [24] and Karenlampi and Houpis, (1986) [25].

\section{CHLOROPHYLL FLUORESCENCE}

The chlorophyll fluorescence parameters of steadystate fluorescence $\left(F_{s}\right)$, quantum yield $\left(F_{m}^{\prime}-F_{s} / F_{m}^{\prime}\right)$ and max quantum yield $\left(F_{v}^{\prime} / F_{m}^{\prime}\right)$ were measured on $G$. insignis at elevations of 2673, 2773, 2789 and 2950 meters (Table 2). Electron transport rate (ETR) was calculated, using the LI-COR algorithm, in simultaneous measurements. Measurements of chlorophyll fluorescence parameters were utilized to evaluate the stress effects imposed on PSII photochemistry and the physiological correlations between leaf-level gas exchange and chlorophyll fluorescence of plants under stress from elevated $\mathrm{SO}_{2}$ and $\mathrm{CO}_{2}$ concentrations, identified as the second main objective of this study. Results reveal steadystate-fluorescence $\left(F_{s}\right)$ and interaction between $\mathrm{SO}_{2}$ and $\mathrm{CO}_{2}$ concentrations are moderately correlated and $F_{s}$ and $A$ are weakly correlated with $\left(r^{2}=0.450,0.113\right)$, respectively.

The relationship between steady state chlorophyll fluorescence, quantum yield and maximum quantum yield and gas exchange measurements of $A, g_{s}$ and $C_{i}$ is complex and influenced by environmental factors, as well as physiological adaptations. Dobrowski et al., (2005) [26] emphasized that the relationship between $F_{s}$ and $A$ is mediated through competing de-excitation pathways of photochemical quenching and non-photochemical quenching. This relationship shows a direct and inverse relationship depending on the intensity of the stress and the status of the alternate de-excitation pathways.

Chlorophyll fluorescence parameters; $F_{m}^{\prime}-F_{s} / F_{m}^{\prime}$ and ETR are strongly correlated with atmospheric $\mathrm{SO}_{2}$ concentrations $\left(\mathrm{r}^{2}=0.801\right.$ and 0.799$)$, respectively. However, ETR and $A$, and $F_{m}^{\prime}-F_{s} / F_{m}^{\prime}$ and $A$ show weak 
Table 2. Chlorophyll fluorescence parameters measured on Gunnera insignis at different elevations with corresponding $\mathrm{SO}_{2}$ concentrations.

\begin{tabular}{cccccc}
\hline Elevation & $\mathrm{SO}_{2}$ & $\begin{array}{c}\text { Steady-State Fluores- } \\
\text { cence }\end{array}$ & Quantum Yield & Max Quantum Yield & Electron Transport Rate \\
\hline$($ meters $)$ & $(\mathrm{ppm})$ & $\left(F_{s}\right)$ & $\left(F_{m}^{\prime}-F_{s} / F_{m}^{\prime}\right)$ & $\left(F_{v}^{\prime} / F_{m}^{\prime}\right)$ & 0.611 \\
2673 & 0.182 & 843.8 & 0.189 & 0.664 & 96.669 \\
2773 & 0.137 & 1040.2 & 0.198 & 0.715 & 101.158 \\
2789 & 0.076 & 1074.4 & 0.207 & 0.741 & 105.588 \\
2950 & 0.281 & 927.7 & 0.189 & & 96.38 \\
\hline
\end{tabular}

correlations $\left(\mathrm{r}^{2}=0.217\right.$ and $\left.\mathrm{r}^{2}=0.231\right)$, respectively, suggesting the induction of a non-photosynthetically productive metabolic pathway which could potentially provide a target mechanism for a remotely sensed measure of overall plant health. Previous studies have identified potentially large alternative electron sinks that contribute to photo-protection which are particularly important in plants growing for extended periods under of stressful conditions [27-30]. Alternative-acceptor-dependent photoprotection via $\mathrm{O}_{2}$, the water-water cycle, nitrate, sulphate, light-stimulated synthesis of fatty acids, and oxaloacetate reduction are among a list of suggested mechanisms which may enable the progression of ETR under stress conditions to maintain rates similar to those of non-stressed leaves [30].

Zarco-Tejada et al., (2003) [31] state, "In general, steady-state chlorophyll fluorescence is low when photosynthesis is high. However, chlorophyll fluorescence can also decline when photosynthesis is low, because of an intensified protective quenching action on chlorophyll fluorescence production. Under increasing stress, plant tissues shift toward increasing heat production to dissipate excess energy, and this tends to have the effect of reducing chlorophyll fluorescence production, at least in the initial and intermediate stages of stress". These observations suggest that under these environmental conditions it is not possible to estimate $A$ directly from $F_{s}$, which is consistent with previous findings [26,32,33].

\section{REMOTELY SENSED REFLECTANCE}

A standard reflective index used in remote sensing work is the normalized difference vegetation index (NDVI), which is an index of chlorophyll content calculated from $(R 750-675) /(R 750+R 675)[34]$. A revised version of the NDVI, which is based on a strong correlation and sensitivity to a range of chlorophyll a concentrations and shifts in the Red-Edge is defined as chl NDI or mNDVI $(R 750-705) /(R 750+R 705) \quad[12,35$, 36]. The photochemical reflective index (PRI), which is based on reflectance at $531 \mathrm{~nm}$ and calculated as $(R 531-570) /(R 531+570)$ provides a strong estimate of photosynthetic efficiency for most species [37]
To most accurately track subtle changes in $F_{s}$, the double-peak optical index (DPi) was utilized, calculated from $(D 688 \times D 710) / D 697^{2}[31]$. Due to the complexity of different study methods and field conditions, such as instruments used, analytical methods, characteristics of the species tested and changing environmental conditions, no one method has been universally adopted as satisfactory under all growth and environmental conditions [38].

Leaf level reflectance data from sample plants were gathered using a portable spectrometer (UniSpec, PP systems, Haverhill, MA), 1 meter above vegetation. Remotely sensed spectra for intact leaves of $\mathrm{G}$. insignis were measured at elevations of 1939, 2594, 2673, 2789 and 2950 meters with $\mathrm{SO}_{2}$ concentrations of $\mathrm{n} / \mathrm{d}, 0.053$, $0.1823,0.0755$ and $0.2805 \mathrm{ppm}$, respectively (Table 3).

The third main objective of this research was to provide evidence that remotely sensed reflectance-derived fluorescence ratio indices can be used to monitor plant stress and photosynthetic functioning. Leaf reflectance of $\mathrm{SO}_{2}$ stressed plants show that in at least some cases, there were significant changes and shifts that could be detected remotely. When comparing the shifts and changes in reflectance across a wide range of wave-lengths there are general trends, but a few inconsistencies. These inconsistencies could have been caused by frequently changing environmental conditions, such as changing light conditions and precipitation causing differences in reflectance.

Reflectance spectra for $G$. insignis measured at elevations 2673 and 2950 meters with $\mathrm{SO}_{2}$ concentrations of 0.1823 and $0.2805 \mathrm{ppm}$, respectively, show maximum shifts in the Red-Edge region and maximum reflected PAR (Figure 2). As expected and previously reported [39-42] the maximum of the first derivative (the inflecttion point of the red-edge, IPP) shifted toward shorter wavelengths, due to pigment degradation. Gates et al., 1965 [43] provided observations that chlorosis caused by the loss of chlorophyll induces an increase in reflectance across the visible spectrum, which causes a blue shift of the IPP. In addition, Rock et al., (1988) [41] displayed air pollution results in a blue shift of the IPP due to loss of 
Table 3. Remotely sensed reflectance indices.

\begin{tabular}{cccccccc}
\hline $\begin{array}{c}\text { Elevation } \\
\text { (meters) }\end{array}$ & $\begin{array}{c}\mathbf{S O}_{2} \\
(\mathrm{ppm})\end{array}$ & $\begin{array}{c}\text { Red-Edge } \\
\text { mNDVI }\end{array}$ & $\begin{array}{c}\text { Double Peak } \\
\text { Optical Index Dpi }\end{array}$ & $\begin{array}{c}\text { Photochemical } \\
\text { Reflective Index } \\
\text { PRI }\end{array}$ & $\begin{array}{c}\text { Normalized } \\
\text { Difference } \\
\text { Vegetation } \\
\text { Index NDVI }\end{array}$ & $\begin{array}{c}\text { Modified } \\
\text { Red-Edge mNDI }\end{array}$ & $\begin{array}{c}\text { Reflective } \\
\text { Water Index } \\
\text { WI }\end{array}$ \\
\hline 1939 & $\mathrm{n} / \mathrm{d}$ & 0.585422 & 0.891596 & 0.015323 & 0.86752 & 0.654559 & 1.156297 \\
2594 & 0.053 & 0.475426 & 0.953824 & -0.00723 & 0.73413 & 0.568996 & 1.105463 \\
2673 & 0.182 & 0.505334 & 1.093702 & -0.01248 & 0.78142 & 0.595786 & 1.041003 \\
2789 & 0.076 & 0.626071 & 0.95177 & 0.047125 & 0.85928 & 0.724589 & 1.130384 \\
2950 & 0.281 & 0.433832 & 1.147461 & 0.016208 & 0.65548 & 0.58324 & 1.054046 \\
\hline
\end{tabular}
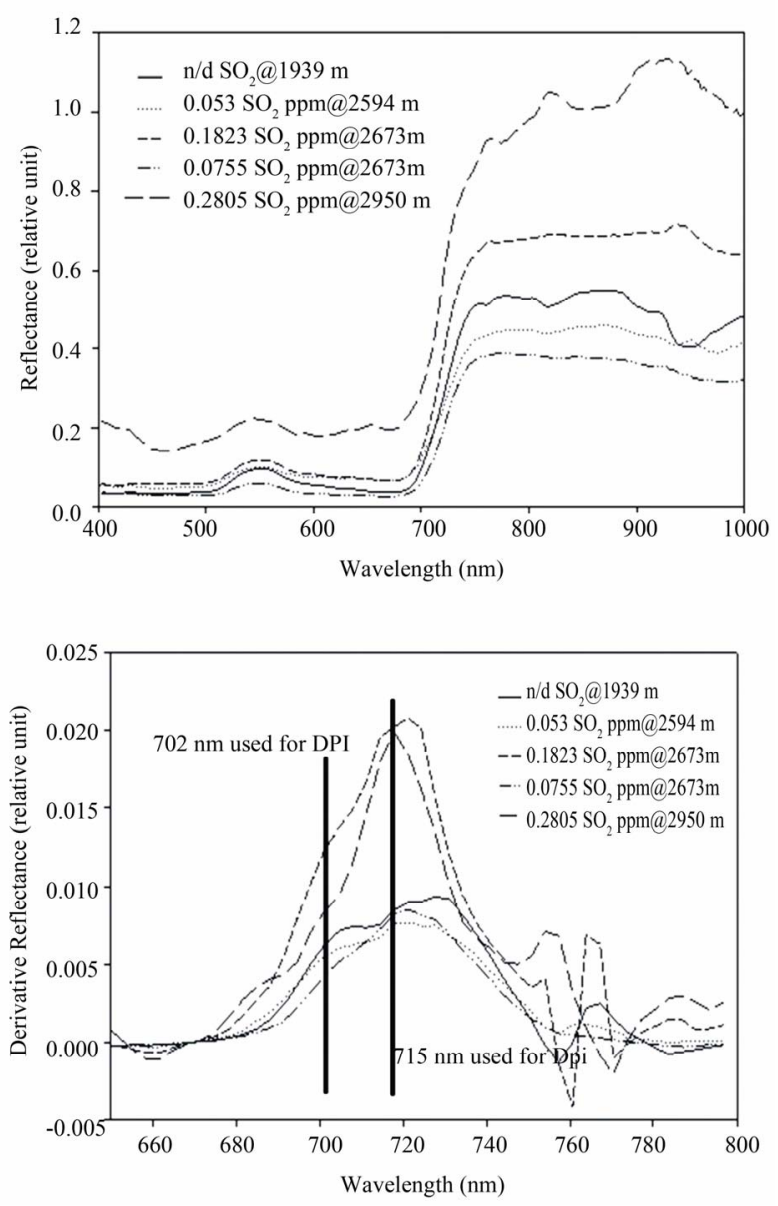

Figure 2. Remotely sensed reflectance and derivative spectrum on a single leaf of Gunnera insignis at different $\mathrm{SO}_{2}$ concentrations, used to calculate Dpi index measured with Unispec-SC portable spectrometer (UniSpec, PP Systems, Haverhill, MA) in the $400-1000$ and $640-820 \mathrm{~nm}$ spectral range, respectively.

chlorophyll b.

Reflectance spectra for $G$. insignis measured at elevations 1939, 2594 and 2789 meters with $\mathrm{SO}_{2}$ concentrations of $\mathrm{n} / \mathrm{d}, 0.053$ and $0.0755 \mathrm{ppm}$, respectively, show minimal shifts in the Red-Edge region and the least reflected PAR (Figure 2). These results generally corre- spond to the highest values of $\mathrm{CO}_{2}$, the highest rates of conductance and the highest $A$ rates. The $\mathrm{SO}_{2}$ and $\mathrm{CO}_{2}$ relationship will be discussed in a following section, but should be noted throughout these measurement results.

The most useful reflective index incorporated in this study was that based on the double-peak (Dpi) feature in the $700-715 \mathrm{~nm}$ spectral region, as reported and demonstrated by Zarco-Tejada et al., 2003 [31]. Strong correlations were calculated between Dpi and $\mathrm{SO}_{2}$, $F_{m}^{\prime}-F_{s} / F_{m}^{\prime}$, ETR and $\mathrm{CO}_{2}$ with $\mathrm{r}^{2}=0.975,0.945,0.942$ and 0.801, respectively. Moreover, Dpi is at least moderately correlated with every physiological measurement in this study.

It has been previously reported that the double-peak indicator of fluorescence emission can be detected at times of higher fluorescence emission can disappear during times of lowest fluorescence emission [31], corroborating results were found in this study (Figure 2). However, Zarco-Tejada et al., 2003 [31] observed this double-peak feature as diminishing with increasing stress induction. Confounding results from this study are seen in (Figure 2 and Table 3), which show the greatest Dpi value of 1.148 and 1.094, corresponding to the highest level of $\mathrm{SO}_{2}$ concentration of 0.2805 and $0.1823 \mathrm{ppm}$, respectively. The Dpi index in this study was developed as a modified optical index calculated using D702 $\times$ D715/(D708 $)^{2}$. The above mentioned results suggest the Dpi using D702 $\times$ D $715 /(D 708)^{2}$ is capable of remotely tracking $\mathrm{SO}_{2}$ induced stress under natural conditions.

In this study, ground based leaf-level reflectance measurements allowed the evaluation of $\mathrm{SO}_{2}$ induced stress and showed that shifts in the IPP toward shorter wavelengths and greater maximum values corresponded with $\mathrm{SO}_{2}$ stress. And thus the incorporated reflectance indices appear to be a valid tool for remote tracking of $\mathrm{SO}_{2}$ induced stress.

\section{SULPHUR DIOXIDE AND CARBON DIOXIDE RELATIONSHIP}

Passive monitoring was conducted to determine atmospheric gas concentrations of $\mathrm{SO}_{2}$ using Ogawa Pas- 
sive Air Sampler's [44]. Lab analyses of $\left[\mathrm{SO}_{2}\right]$ were conducted at Anatek Lab, in Moscow, Idaho. $\left[\mathrm{CO}_{2}\right]$ measurements were taken using a Vaisala CARBOCAP Hand-Held Carbon Dioxide Meter GM70 with a GMP222 Carbon Dioxide Probe [45].

This study site is a natural environment with high gas emission activity with significant $\mathrm{SO}_{2}$ emission. However, along with the increased $\mathrm{SO}_{2}$ emission a substantial increase in $\mathrm{CO}_{2}$ concentration was identified (Table 1). Previous studies have reported an increase in $A$ due to $\mathrm{CO}_{2}$ enrichment, which has been attributed to an increase in substrate availability for Rubisco [46]. The reduction in $g_{s}$ due to high $\mathrm{CO}_{2}$ concentrations is a well known phenomenon, however this reduction would be expected to reduce the $\mathrm{SO}_{2}$ flux into the leaf interior, which would reduce the effective dose of $\mathrm{SO}_{2}$ [47]. The role of $\mathrm{CO}_{2}$ enrichment in protecting plants against harmful airborne pollutants has been reported in previous studies $[48,49]$.

This $\mathrm{SO}_{2}$ and $\mathrm{CO}_{2}$ relationship is very apparent in the measurements and observations collected around the fault scarp at the 2789 meters sampling site (Table $\mathbf{1}$ and Figure 1). The fault scarp likely facilitates $\mathrm{CO}_{2}$ accumulation, either by virtue of $\mathrm{CO}_{2}$ emissions along the fault plane and/or $\mathrm{CO}_{2}$ not being blown away from the low area due to topography. Measurements collected within the fault scarp seem to be influenced from the sharp drop in $\mathrm{SO}_{2}$ from 0.1374 to $0.0755 \mathrm{ppm}$ and back up to 0.2805 ppm (Table 1) and a sharp rise in $\mathrm{CO}_{2}$ from $440 \mathrm{ppm}$ to $517 \mathrm{ppm}$ and back down to $430 \mathrm{ppm}$ (Table 1). Gas exchange measurements of $A$ and $g_{s}$ (Table 1), chlorophyll fluorescence parameters of $F_{s},\left(F_{m^{-}}^{\prime} F_{s} F_{m}^{\prime}\right)$ and ETR (Table 2) and remotely sensed reflectance indices of mNDVI, PRI and mNDI were all highest at this sample site (Table 3).

To emphasize the physiological interaction $\mathrm{SO}_{2}$ and $\mathrm{CO}_{2}$ concentrations have on vegetation, the capability of the interaction and induced effects to be remotely detected using the Dpi index a ratio of $\mathrm{SO}_{2} / \mathrm{CO}_{2}$ concentrations was developed and correlated with the Dpi index results. The $\mathrm{SO}_{2} / \mathrm{CO}_{2}$ ratio and Dpi index are strongly correlated $\left(r^{2}=0.927\right)$. Previous studies have shown that physiological and physical measurements of plants exposed to elevate $\mathrm{CO}_{2}$ and $\mathrm{SO}_{2}$ were similar to those observed for $\mathrm{CO}_{2}$ enrichment only [47]. The findings of this study lend further support to the observed relation of the phytotoxic effect of $\mathrm{SO}_{2}$ is reduced by the positive physiological responses plant undertake when exposed to increase concentration of $\mathrm{CO}_{2}$ [47].

Limitation of plant growth and/or quantification of $\mathrm{SO}_{2}$ induced stress cannot be assigned to a single physiological process or measurement. The direction and magnitude of the physiological alteration is not completely clear, and plants' resistance to $\mathrm{SO}_{2}$ varies depending on the plant species [50]. However, the results of this study may be used to gain a better understanding of the impacts of volcanically emitted $\mathrm{SO}_{2}$ on the species studied, different species, the ecosystem and different environments under elevated $\mathrm{SO}_{2}$ loading.

From a general analysis of the data collected along the edge of this kill zone, it may be concluded that $\mathrm{SO}_{2}$ affects $G$. insignis gas exchange, chlorophyll fluorescence and reflectance in a variety of ways, which were in some cases buffered by elevated $\mathrm{CO}_{2}$ concentration. The results of this study show that elevated $\mathrm{CO}_{2}$ mitigated the damaging effects of $\mathrm{SO}_{2}$ in $G$. insignis. This study indicates that $G$. insignis growing in the volcanically emitted $\mathrm{SO}_{2}$ toxic region of Volcán Turrialba has developed a physiological adaptive mechanism that enables the plant to survive. One point to consider is the easily observable chlorosis on mature leaves of G. insignis, as opposed to the non-visible effects on younger leaves, which suggests the plants resource partitioning mechanisms that allow young leaves to remain relatively healthy despite high $\mathrm{SO}_{2}$ levels, but eventually the adaptive adjustments break down and leaves die. While adaptive responses may develop in certain species and genotypes, most will eventually succumb to elevated $\mathrm{SO}_{2}$.

It should not be overlooked that results and physiological responses of the study plants in this research could have been confounded by the presence of other volcanically emitted air pollutants and possibly a multitude of non-measured environmental perturbations. However, environmental conditions such as light, moisture and photoperiod remain fairly constant at these latitudes. Most field experiments have not been able to separate and distinguish between the physiological effects of individual pollutants when they occur in mixtures.

Relationships identified between $\mathrm{SO}_{2}$ and the Dpi index developed using D702 $\times$ D715/(D708) $)^{2}$, Dpi and quantum yield and Dpi and electron transport rate $\left(\mathrm{r}^{2}=\right.$ $0.975,0.945$ and 0.942), respectively, along this $\mathrm{SO}_{2}$ gradient further demonstrate the validity to the already well documented capability of the Dpi index to track chlorophyll fluorescence. Results of this study add to the increasing evidence that remote sensing and derivative reflectance analysis is capable of identifying plant stress under natural conditions. The capability and extent to which this study's findings can be extrapolated to larger scale detection of $\mathrm{SO}_{2}$ induced stress using aerial and/or satellite imaging should be further explored. Validation of this study's results via similar experiments on vegetation surrounding other volcanoes with similar gas emissions would be of great value. With the above mentioned recent increased volcanic activity of Volcán Turrialba and the importance of the surrounding agricultural areas to the locals, the region and the country; particular invested research in both monitoring the volcanic activity and 
Table 4. NDVI values from Landsat 5 TM and Landsat 7 ETM+ images and ground measurements.

\begin{tabular}{cccccc}
\hline Elevation & Dec.13 & Dec.27 & Jan.15 & Apr.5 & Ground Data \\
\hline$(\mathrm{m})$ & 2000 & 2008 & 2010 & 2010 & (May 2010) \\
1939 & 0.8157 & 0.809 & 0.7579 & 0.7654 & 0.8675 \\
2594 & 0.8011 & 0.6445 & 0.696 & 0.7942 & 0.7341 \\
2673 & 0.6789 & 0.7279 & 0.474 & 0.5524 & 0.7814 \\
2789 & 0.7867 & 0.7692 & 0.7458 & 0.5958 & 0.8593 \\
2950 & 0.7332 & 0.6895 & 0.5729 & 0.4377 & 0.6555 \\
\hline
\end{tabular}
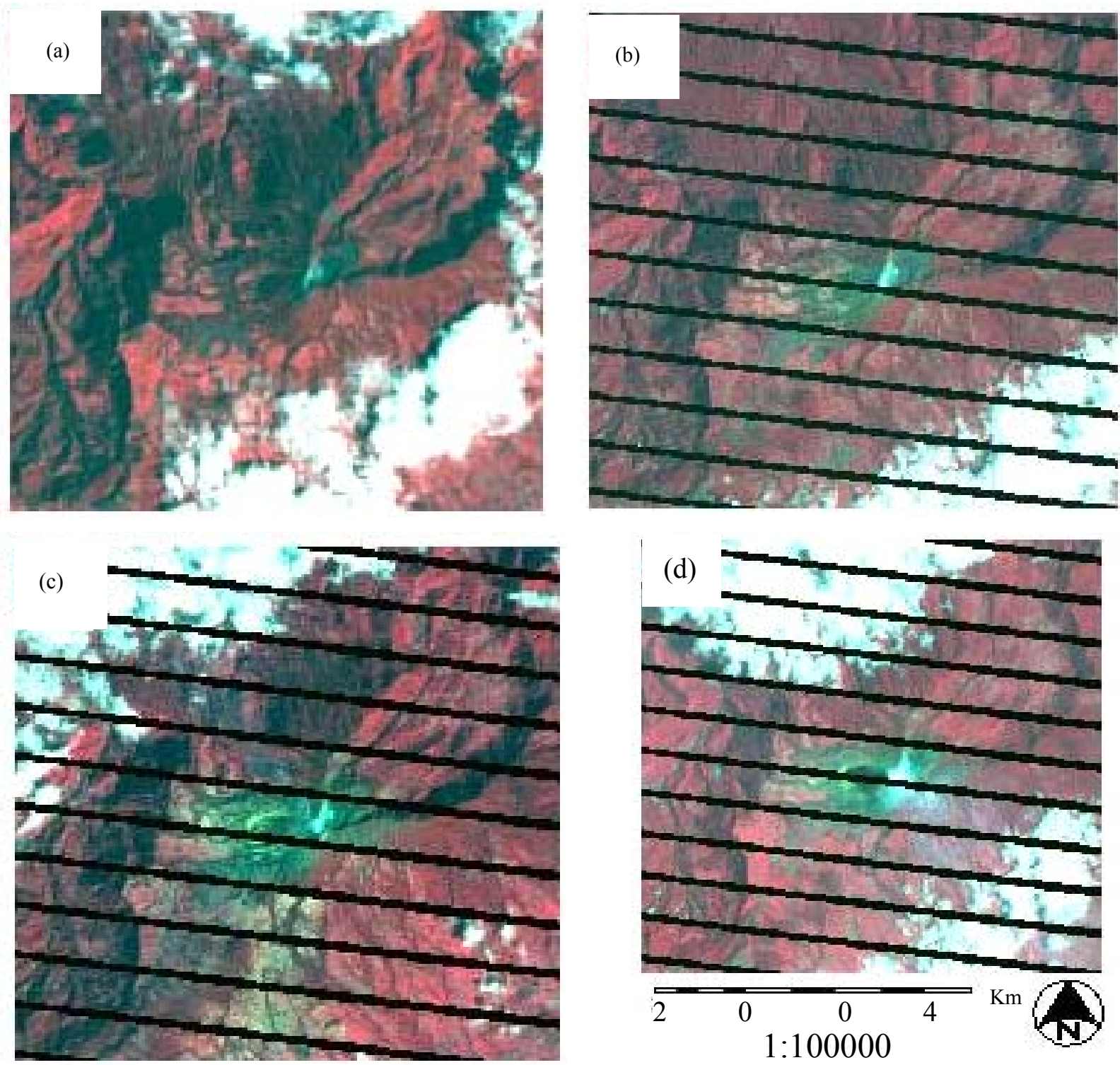

Figure 3. Landsat TM and ETM+ derived false color composites, near infra-red shown as red, red shown as green and green shown as blue $(4,3,2)$ time series of images used to calculate vegetation indices along the elevation gradient sampled on site (Table 4). (a) Dec.13, 2000; (b) Dec. 27, 2008; (c) Jan. 15, 2010; and (d) April. 5, 2010. Horizontal white lines are due to the scan line corrector error present in Landsat ETM+ data following its failure in 2003. 


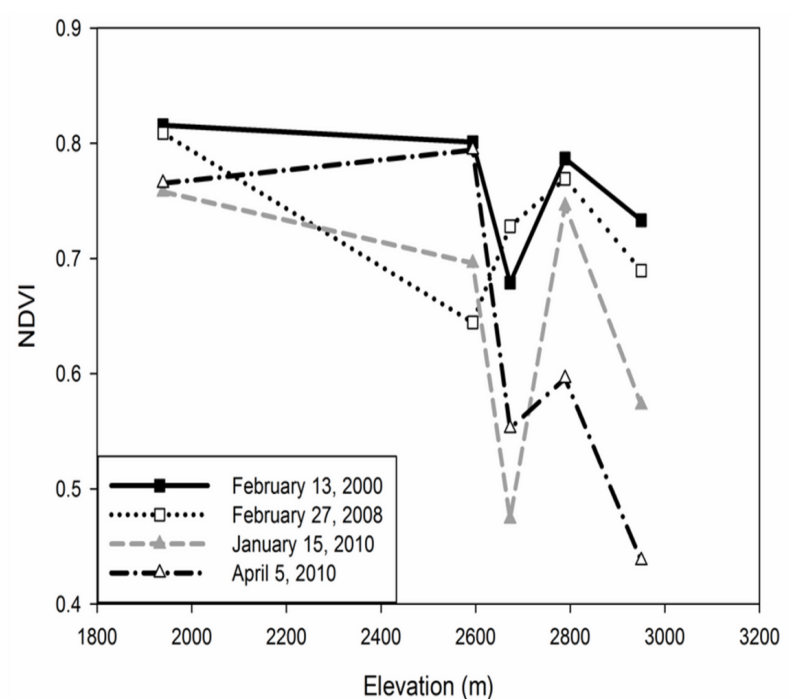

Figure 4. NDVI extracted from available Landsat 5 TM scene and three Landsat 7 ETM+ scenes over Costa Rica. Each point represents the NDVI of a 30 meter pixel along an elevation gradient following the edge of the natural disaster.

surrounding vegetative response is warranted.

\section{PERSPECTIVE}

This initial examination has highlighted potential physiological measurements to describe effects of volcanic emissions on G. insignis as an indicator species, but can be used to emphasize and focus future experiments; from direct leaf level physiological and reflective measurements on single individuals to ecosystem scale remote sensing with aerial and satellite imaging capabilities. As proof of this concept, NDVI values were determined from Landsat $5 \mathrm{TM}$ and Landsat $7 \mathrm{ETM}+$ data using the USGS GLOVIS tool, for temporal periods predating and concurrent with the volcanic activity as well as a fourth scene acquired close to the dates of the field campaign: February 13, 2000, February 27, 2008, January 15, 2010 and April 5, 2010, respectively (Table 4 and Figure 3). The raw Digital Number (DN) values were converted to top-of-atmosphere reflectance with dark object subtracttion (TOA-DOS) to account for atmospheric effects [51]. We then processed the imagery through a Matlab script that calculated NDVI and queried pixels according to a list of GPS coordinates relating elevation to sampling location from the field campaign. Figure 4 shows the results of the ETM+ analysis.

When NDVI values are plotted along the elevational gradient (Figure 4), a trend is easily identified. The first data point (elevation $=1939 \mathrm{~m}$ ) plotted in Figure 4 represents the control site with no detectable $\mathrm{SO}_{2}$, and highest NDVI values. The second data point (elevation $=$ $2594 \mathrm{~m})$ represents minimal $\mathrm{SO}_{2}$ stress $\left(\mathrm{SO}_{2}=0.053\right.$ ppm) with NDVI values dropping from the previous site (Table 4). The third data point (elevation $=2673$ ) represents extreme $\mathrm{SO}_{2}$ induced stress $\left(\mathrm{SO}_{2}=0.1823 \mathrm{ppm}\right)$ with moderate $\mathrm{CO}_{2}$ buffering $\left(\mathrm{CO}_{2}=460 \mathrm{ppm}\right)$ and dramatic drops in NDVI values. The next data point, we have referred to as "fault scarp" (elevation $=2789 \mathrm{~m}$ ); this site displays the greatest $\mathrm{CO}_{2}$ buffering $\left(\mathrm{CO}_{2}=517\right.$ $\mathrm{ppm})$ from $\mathrm{SO}_{2}$ induced stress $\left(\mathrm{SO}_{2}=0.0755 \mathrm{ppm}\right)$, which is clearly demonstrated in the satellite derived NDVI values. The final data point in Figure 4, represents the most extreme $\mathrm{SO}_{2}$ induced stress $\left(\mathrm{SO}_{2}=0.2805 \mathrm{ppm}\right)$ and least $\mathrm{CO}_{2}$ buffering potential $\left(\mathrm{CO}_{2}=430 \mathrm{ppm}\right)$.

While the interactions between $\mathrm{SO}_{2}$ and $\mathrm{CO}_{2}$ are difficult to assess and whether the emissions are anthropogenic or natural, the ability to determine potential phytotoxic induced mortality can greatly limit the consequences and extent of damage. For a more effective assessment and possible control of the effects of atmospheric pollutants on tropical plants and forests, human health and the environment, it is necessary to further develop strategies, test hypotheses and build models for regional and ecosystem monitoring, that are economically viable, and can be used in remote areas.

\section{REFERENCES}

[1] National Seismological Network. (2010) Turrialba volcano, costa rica current activity. Preliminary Report, Red Sismolo'gica Nacional, 4-10 January 2010, pp. 1-6.

[2] Lanly, J.P. (1982) Tropical Forest Resources. FAO Forestry Paper 30, United Nations Food and Agricultural Organization, Rome.

[3] Collins, N.M., Sayer, J.A. and Whitmore, T.C. (1991) The conservation atlas of tropical forests Asia and the Pacific. Simon and Schuster, New York.

[4] Food and Agricultural Organization (1993) Forest resources assessment 1990: Tropical countries. FAO Forestry Paper 112, United Nations Food and Agricultural Organization, Rome.

[5] Primack, R.B. and Lovejoy, T.E. (1995) Ecology, conservation, and management of southeast Asian rainforests. Yale University Press, New Haven.

[6] Laurance, W.F. and Bierregaard, R.O. (1997) Tropical forest remnants: Ecology, management, and conservation of fragmented communities. University of Chicago Press, Chicago.

[7] Whitmore, T.C. (1997) Tropical forest disturbance, disappearance, and species loss. In: Laurance, W.F. and Bierregaard, R.O., Eds., Tropical Forest Remnants: Ecology, Management, and Conservation of Fragmented Communities, University of Chicago Press, Chicago, 3-12.

[8] Laurance, W.F. (1998) A crisis in the making: Responses of Amazonian forests to land use and climate change. Trends in Ecology and Evolution, 13, 411-415.

[9] Brooks, T.M., Pimm, S.L. and Oyugi, J.O. (1999) Time 
lag between deforestation and bird extinction in tropical forest fragments. October, 13, 1140-1150.

[10] Laurance, W.F. (1999) Reflections on the tropical deforestation crisis. Biological Conservation, 91, 109-117. doi:10.1016/S0006-3207(99)00088-9

[11] Panicucci, A., Nali, C. and Lorenzini, G. (1998) Differential photosynthetic response of two mediteranian species (Arbutus unedo and Viburnum tinus) to sulphur dioxide. Chemosphere, 36, 703-708. doi:10.1016/S0045-6535(97)10111-4

[12] Gamon, J.A. and Surfus, J.S. (1999) Assessing leaf pigment content and activity with a reflectometer. New Phytologist, 143, 105-117. doi:10.1046/j.1469-8137.1999.00424.x

[13] Rasmuson, M. (2002) Fluctuating asymmetry-indicator of what. Hereditas, 136, 177-183. doi:10.1034/j.1601-5223.2002.1360301.x

[14] Omasa, K. and Takayama, K. (2002) Image instrumentation of chlorophyll a fluorescence for diagnosing photosynthetic injury. In: Omasa, K., Saji, H., Youssefian, S. and Kondo, N., Eds., Air Pollution and Plant Biotechnology, Springer-Verlag, Berlin, 287-308.

[15] Boyer, J.N., Houston, D.B. and Jensen, K.F. (1986) Impacts of chronic $\mathrm{SO}_{2}, \mathrm{O}_{3}$, and $\mathrm{SO}_{2}+\mathrm{O}_{3}$ exposures on photosyn-thesis of Pinus strobes clones. European Journal of Plant Pathology, 16, 293-299. doi:10.1111/j.1439-0329.1986.tb00194.x

[16] Darrall, N.M. (1989) The effect of air pollutants on physiological processes in plants. Plant Cell and Environment, 12, 1-30. doi:10.1111/j.1365-3040.1989.tb01913.x

[17] De Kok, L.J. (1990) Sulphur metabolism in plants exposed to atmospheric sulphur, sulphur nutrition and sulphur nutrition assimilation in higher plants, fundamental, environmental and agricultural aspects. SPB Academic Publishing, Hague, 125-138.

[18] Mooser, F., Meyer-Abich, H. and McBirney, A.R. (1958) Catalogue of the active volcanoes of the world including solfatra fields. International Volcanological Association, Part VI Central America, 6, 144-145.

[19] Alvarado, G.E. and Soto, G.J. (2008) Volcanoes in the preColumbian life, legend, and archaeology of Costa Rica (Central America). Journal of Volcanology and Geothermal Research, 176, 356-362. doi:10.1016/j.jvolgeores.2008.01.032

[20] Palkovic, L. (1978) A hybrid of Gunnera from Costa Rica. Systematic Botany, 3, 226-235. doi:10.2307/2418316

[21] LI-COR Bioscience, Inc. (2004) Using the LI-6400 portable photosynthesis system, Lincoln, NE, LI-COR Bioscience, Inc.

[22] Black, V.J and Unsworth, M.H. (1980) Stomatal response to sulphur dioxide and vapour pressure deficit. Journal of Experimental Botany, 31, 667-677. doi:10.1093/jxb/31.2.667

[23] Dodd, I.C. and Doley D. (1998) Growth responses of cucumber seedlings to sulphur dioxide fumigation in a tropical environment. Environmental and Experimental Botany, 39, 41-47. doi:10.1016/S0098-8472(97)00034-8
[24] Barton, J.R., McLaughlin, S.B. and McConathy, R.K. (1980) The effects of $\mathrm{SO}_{2}$ on components of leaf resistance to gas exchange. Environmental Pollution Series A, Ecological and Biological, 21, 255-265. doi:10.1016/0143-1471(80)90129-4

[25] Karenlampi, L. and Houpis, J.L.J. (1986) Structural condition of mesophyll cells of Pinus-ponderosa-var-scopulorum after sulfur dioxide fumigation. Canadian Journal of Forest Research, 16, 1381-1385. doi:10.1139/x86-246

[26] Dobrowski, S.Z., Pushnik, J.C., Zarco-Tejada, P.J. and Ustin, S. (2005) Simple reflectance indices track heat and water stress-induced changes in steady-state chlorophyll fluorescence at the canopy scale. Remote Sensing of Environment, 97, 403-414. doi:10.1016/j.rse.2005.05.006

[27] Cornic, G., Le Gouallec, J.L., Briantais, J.M. and Hodges, M. (1989) Effect of dehydration and high light on photosynthesis of two C3 plants. Phaseolus vulgaris L. and Elastostema repens. Planta, 177, 84-90. doi:10.1007/BF00392157

[28] Renou, J.L., Gerbaud, A., Just, D. and Andre, M. (1990) Different substomatal and chloroplastic $\mathrm{CO}_{2}$ concentration in water-stressed wheat. Planta, 182, 415-419. doi:10.1007/BF02411393

[29] Noctor, G., Veljovic-Jovanovic, S., Driscoll, S., Novitskaya, L. and Foyer, C.H. (2002) Drought and oxidative load in the leaves of $\mathrm{CO}_{3}$ plants: A predominant role for photorespiration. Annals of Botany, 89, 841-850. doi:10.1093/aob/mcf096

[30] Ort, D.R. and Baker, N.B. (2002) A photoprotective role for $\mathrm{O}_{2}$ as an alternative electron sink in photosynthesis. Current Opinion in Plant Biology, 5, 193-198. doi:10.1016/S1369-5266(02)00259-5

[31] Zarco-Tejada, P.J., Pushnik, J.C., Dobrowski, S. and Ustin, S.L. (2003) Steady-state chlorophyll a fluorescence detection from canopy derivative reflectance and doublepeak red-edge effects. Remote Sensing of Environment, 84, 283-294. doi:10.1016/S0034-4257(02)00113-X

[32] Flexas, J., Escalona, J.M., Evain, S., Gulias, J., Moya, I., Osmond, C. B. and Medrano, H. (2002a) Steady-state chlorophyll fluorescence (Fs) measurements as a tool to follow variations of net $\mathrm{CO}_{2}$ assimilation and stomatal conductance during water-stress in C-3 plants. Physiologia Plantarum, 114, 231-240. doi:10.1034/j.1399-3054.2002.1140209.x

[33] Flexas, J., Bota, J., Escalona, J. M., Sampol, B. and Medrano, H. (2002) Effects of drought on photosynthesis in grapevines under field conditions: An evaluation of stomatal and mesophyll limitations. Functional Plant Biology, 29, 461-471. doi:10.1071/PP01119

[34] Gamon, J.A. and Qiu, H. (1999) Ecological applications of remote sensing at multiple scales. In: Pugnaire, F.I. and Valladares, F., Eds., Handbook of Functional Plant Ecology, Marcel Dekker, Inc., New York, 805-846.

[35] Gitelson, A. and Merzlyak M.N. (1994) Spectral reflectance changes associated with autmn senescence of aesculus hippocastanum L. and Acer platanoides L. leaves: Spectral features and relation to chlorophyll estimation. Journal of Plant Physiology, 143, 286-292. doi:10.1016/S0176-1617(11)81633-0 
[36] Gamon, J.A., Field, C.B., Goulden, M.L., Griffin, K.L., Hartely, A.E., Peñuelas, J. and Valentini, R. (1995) Relationship between NDVI, canopy structure and photosynthesis in three Californian vegetation types. Ecological Application, 5, 28-41. doi:10.2307/1942049

[37] Filella, I., Peñuelas, J., Llorens, L. and Estiarte, M. (2004) Reflectance assessment of seasonal and annual changes in biomass and $\mathrm{CO}_{2}$ uptake of a Mediterranean shrubland submitted to experimental warming and drought. Remote Sensing of Environment, 90, 308-318. doi:10.1016/j.rse.2004.01.010

[38] Ustin, S., Gitelson, A., Jacquemoud, S., Schaepman, M., Asner, G., Gamon, J. and Zarco-Tejada, P. (2009) Retrieval of foliar information about plant pigment systems from high resolution spectroscopy. Remote Sensing of Environment, 113, 567-577. doi:10.1016/j.rse.2008.10.019

[39] Horler, D.N.H., Barber, J. and Barringer, A.R. (1980) Effects of heavy metals on the absorbance and reflectance spectra of plants. International Journal of Remote Sensing, 1, 121-136.

[40] Horler, D.N.H., Dockray, M. and Barber, J. (1983) The red edge of plant leaf reflectance. International Journal of Remote Sensing, 4, 273-288. doi:10.1080/01431168308948546

[41] Rock, B.N., Hoshizaki, T. and Miller, J.R. (1988) Comparison of in situ and airborne spectral measurements of the blue shift associated with forest decline. Remote Sensing of Environment, 24, 109-127. doi:10.1016/0034-4257(88)90008-9

[42] Vogelmann, J.E., Rock, B.N. and Moss, D.M. (1993) Red edge spectral measurements from sugar maple leaves. International Journal of Remote Sensing, 14, 1563-1575. doi:10.1080/01431169308953986

[43] Gates, D.M., Keegan, V.J., Schleter, C. and Weidner, V.R.
(1965) Spectral properties of plants. Applied Optics, 4, 1120. doi:10.1364/AO.4.000011

[44] Ogawa \& Co. (1998) $\mathrm{NO}, \mathrm{NO}_{2}$, and $\mathrm{SO}_{2}$ sampling protocol using the Ogawa sampler, Ogawa \& Co., Pompano Beach.

[45] Vaisala Oyj. (2008) User's guide vaisala CARBOCAP hand-held carbon dioxide meter GM70, Helsinki, Finland, Vaisala Oyj, Helsinki.

[46] Bowes, G. (1993) Facing the inevitable: Plants and increasing atmospheric $\mathrm{CO}_{2}$. Annual Review of Plant Physiology and Plant Molecular Biology, 44, 309-332. doi:10.1146/annurev.pp.44.060193.001521

[47] Verma, M. and Agrawal, M. (1996) Alleviation of injurious effects of $\mathrm{SO}_{2}$ on soybean by modifying NPK nutrients. Agriculture, Ecosystems \& Environment, 57, 49-55. doi:10.1016/0167-8809(95)01000-9

[48] McKee, I.F., Eiblmeier, M. and Polle, A. (1997) Enhanced ozone tolerance in wheat grown at an elevated $\mathrm{CO}_{2}$ concentration. New Phytologist, 137, 275-284. doi:10.1046/j.1469-8137.1997.00801.x

[49] Miller, J.E., Heagle, A.S. and Pursley, W.A. (1998) Influence on soybean response to $\mathrm{CO}_{2}$ enrichment: II. biomass and development. Crop Science, 38, 122-128. doi:10.2135/cropsci1998.0011183X003800010021x

[50] Steubing, L. and Fangmeier, A. (1987) $\mathrm{SO}_{2}$ sensitivity of plant communities in a beech forest. Environmental Pollution, 44, 297-306. doi:10.1016/0269-7491(87)90205-3

[51] Chavez, P.S. Jr. (1989) Radiometric calibration of landsat thematic mapper multispectral images. Photogrammetric Engineering \& Remote Sensing, 55, 1285-1294. 